\title{
Academic Adjustment of Grade VIII Students in Solving Mathematical Word Problems Using K to 12 Curriculum in the Republic of the Philippines
}

\author{
Mary Ann R. Agdan, Lady Jane B. Calderon, Amiel Joseph P. Gabuyo, Jomalyn F. \\ Dalumpines, Jealyn C. Flores, Rosvelinda L. Dequiros \\ Divine Word College of Calapan, Philippines
}

\begin{abstract}
Academic adjustment is adapting to every change in curriculum. Some of the factors that affect the academics are attitudes, motivation, and study habits. Mathematical word problems is one of the main components to this research which will also be a way on how to find out the ability of the students in terms of solving more problems in mathematics using $k$ - 12 curriculum. We conducted this research in order to find out the relationship between academic adjustment and solving mathematical word problems. We used descriptive correlational method of research to seek and investigate whether a relationship exists between two or more variables. It enables you to make more intelligent predictions [1]. Our main respondents were Grade VIII students at Oriental Mindoro National High School (OMNHS, Philippines). This research is supported by different theories (B.F Skinners, Thorndike, and McClelland). Result revealed that there is significant relationship between the academic adjustment and solving mathematical word problem using $K$ to 12 curriculum [2]. This particular research endeavor will be significant to the target respondents, the school administrators, curriculum planners and implementers, and most especially as a guide for future researchers to investigate fully on related researches about academic adjustment. Moreover, it may also be a reference in the global setting on how Grade VIII students in an ASEAN country like the Philippines adjust to curriculum changes.
\end{abstract}

\section{Introduction}

Education is nothing without curriculum. Academic adjustments occur when new curriculum is being integrated. Since Philippines is the only country in Asia having 10 years of basic education, academic adjustment and alignment is necessary. The enhanced $\mathrm{K}$ to 12 Basic Education Program seeks to provide for a quality 12 - y e a $\mathrm{r}$ basic education program that each Filipino is entitled to. This is consistent with Article XIV, Section 2(1) of

the 1987 Philippine Constitution which states that "The State shall establish, maintain, and support a complete, adequate, and integrated system of education relevant to the needs of the people and society." Meanwhile, the implementation of K to 12 is new to the students and adjustment to improve their academic performance was very challenging. Students may not be ready to a kind of changes Curriculum is dynamic so that changes, specifically the content covered by these subjects are being adjusted. Mathematics is one of the subjects that require further attention in relation to this situation and one of the topics under this discipline is solving mathematical problems which is the main focus of this study. Solving problems is at the heart of mathematics.

It is for these reasons that the researchers would like to determine the Academic Adjustment of Grade VIII Students in Solving Mathematical Word Problems using K to 12 Curriculum.

\section{Literature Review}

Preiss and Franova [3] analyzed the relationship between depressive symptoms, academic achievement and intelligence. The data were collected from the sample of 635 school children consisting 304 boys and 331 girls by using Wechsler's intelligence scale for children and grade point average. The findings indicated that there was no gender difference in academic achievement of boys and girls. Navarrete et al. [4] carried out a study on culture and achievement motivation in Latino and Anglo-American high school students of USA on a sample of 149 students from the high school districts in California. Data were collected by administering culture value orientation and attribution-emotion scale to the sample and grade point average was taken as academic achievement measures of the students. Tella [5] investigated the impact of motivation on academic achievement in mathematics. The participants of the study were 
450 secondary schools' students of both sexes drawn from ten schools of Ibadan. Data were collected by employing achievement test in mathematics as a measure of academic achievement of male and female students in mathematics. Male students were found to have better achievement in mathematics. Ilogu [6] investigated the effect of achievement motivation on students' cognitive performance behavior. A sample 200 students was selected by stratified random sampling from Lagos. Achievement motivation scale and senior secondary school certificate were used to collect data from the students. Results of the study indicated significant positive relationship between achievement motivation and students' academic achievement.

\section{Methodology}

The researcher used descriptive-correlational method in this study. The respondents were 90 grade VIII students enrolled during school year 2015- 2016 at Oriental Mindoro National High School. In order to determine the academic adjustment of grade VIII students in solving mathematical word problem using $\mathrm{k}$ to 12 curriculum, the researchers used a 20-item questionnaire. It is composed of four parts with five questions each part. All responses to be provided by the respondents were tabulated and scored based on the five-point numerical scale. Each point obtained corresponding verbal description having the scale of 1.00-1.79 interpreted as low, 1.80-2.59, interpreted as moderately low, 2.60-3.39, interpreted as neutral, 3.40-4.19, interpreted as moderately high and 4.20-5.00, interpreted as high. The level of academic performance of the respondents in problem solving was interpreted using the following scales and descriptions: 75 and below interpreted as very low performance; 76-81, interpreted as low performance; 82-87, interpreted as average performance; 88-93, interpreted as superior performance; and 94-100, interpreted as excellent performance.

\section{Analysis of Findings}

The analysis of findings is outlined in the Tables below.
Table 1. Mean status of the respondents on status of academic adjustment of grade VIII students in terms of attitudes

\begin{tabular}{|c|c|c|c|c|c|}
\hline$\dot{\mathrm{z}}$ & Items & $\stackrel{\mathbb{J}}{\stackrel{\Xi}{\Sigma}}$ & 卷 & 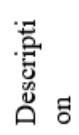 & 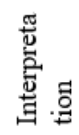 \\
\hline 1 & $\begin{array}{l}\text { I do not panic when I } \\
\text { am required to solve } \\
\text { some problems on } \\
\text { the board }\end{array}$ & 3.73 & 1 & Often & Good \\
\hline 2 & $\begin{array}{c}\text { I feel relaxed in } \\
\text { solving complicated } \\
\text { problems. }\end{array}$ & 3.12 & 5 & $\begin{array}{l}\text { Some } \\
\text { times }\end{array}$ & Fair \\
\hline 3 & $\begin{array}{l}\text { I enjoy solving word } \\
\text { problems }\end{array}$ & 3.48 & 4 & $\begin{array}{l}\text { Some } \\
\text { times }\end{array}$ & Fair \\
\hline 4 & $\begin{array}{l}\text { I can show the } \\
\text { pertinent solutions of } \\
\text { the problem }\end{array}$ & 3.49 & 3 & $\begin{array}{l}\text { Some } \\
\text { times }\end{array}$ & Fair \\
\hline 5 & $\begin{array}{l}\text { I can finish solving } \\
\text { the problem within } \\
\text { time allotted }\end{array}$ & 3.58 & 2 & Often & Good \\
\hline & Overall Mean & 3.48 & & $\begin{array}{l}\text { Some } \\
\text { times }\end{array}$ & Fair \\
\hline
\end{tabular}

Table 2. Mean Status of the respondents on the status of academic adjustment of grade VIII students in terms of motivation

\begin{tabular}{|c|c|c|c|c|c|}
\hline & Items & & & \\
\hline Z & $\begin{array}{c}\text { I listen attentively } \\
\text { during class } \\
\text { discussion }\end{array}$ & 3.81 & 2.5 & Often & Good \\
\hline 1 & $\begin{array}{c}\text { I raise questions } \\
\text { during class } \\
\text { discussion }\end{array}$ & 3.11 & 4 & $\begin{array}{c}\text { Some } \\
\text { times }\end{array}$ & Fair \\
\hline 3 & $\begin{array}{c}\text { I prefer to study with } \\
\text { my peers }\end{array}$ & 3.81 & 2.5 & Often & Good \\
\hline 4 & $\begin{array}{c}\text { I prefer to study } \\
\text { alone }\end{array}$ & 2.99 & 5 & $\begin{array}{c}\text { Some } \\
\text { times }\end{array}$ & Fair \\
\hline 5 & $\begin{array}{c}\text { I prefer to solve } \\
\text { simple problems }\end{array}$ & 4.19 & 1 & Often & Good \\
\hline & \begin{tabular}{c} 
Overall Mean \\
\hline
\end{tabular} & 3.58 & & Often & Good \\
\hline
\end{tabular}


Table 3. Mean status of the respondents on the status of academic adjustment of grade VIII students in terms of study habits

\begin{tabular}{|c|c|c|c|c|c|}
\hline$\stackrel{\circ}{\circ}$ & Items & $\stackrel{\text { Iี }}{\stackrel{\Xi}{\Sigma}}$ & 萜 & 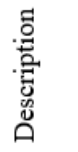 & 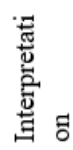 \\
\hline 1 & $\begin{array}{l}\text { I review my past } \\
\text { lessons in order to } \\
\text { inform future } \\
\text { progress }\end{array}$ & 3.47 & 1 & $\begin{array}{l}\text { Some } \\
\text { times }\end{array}$ & Fair \\
\hline 2 & $\begin{array}{l}\text { I study my lessons in } \\
\text { advance }\end{array}$ & 3.28 & 4 & $\begin{array}{l}\text { Some } \\
\text { times }\end{array}$ & Fair \\
\hline 3 & $\begin{array}{c}\text { I participate actively } \\
\text { in the class } \\
\text { discussion }\end{array}$ & 3.6 & 2 & Often & Good \\
\hline 4 & $\begin{array}{c}\text { I spend my vacant } \\
\text { time to study my } \\
\text { lessons }\end{array}$ & 2.99 & 5 & $\begin{array}{l}\text { Some } \\
\text { times }\end{array}$ & Fair \\
\hline 5 & $\begin{array}{l}\text { I do my home works } \\
\text { to submit it on time }\end{array}$ & 3.79 & 1 & Often & Good \\
\hline & Overall Mean & 3.42 & & $\begin{array}{l}\text { Some } \\
\text { times }\end{array}$ & Fair \\
\hline
\end{tabular}

Table 4. Summary of the mean status of academic adjustment

\begin{tabular}{|c|c|c|c|c|}
\hline Variables & Mean & Rank & Description & Interpretation \\
\hline Attitudes & 3.48 & 3 & Sometimes & Fair \\
\hline Motivation & 3.58 & 1 & Often & Good \\
\hline $\begin{array}{c}\text { Study } \\
\text { Habits }\end{array}$ & 3.42 & 2 & Sometimes & Fair \\
\hline $\begin{array}{c}\text { Overall } \\
\text { Mean }\end{array}$ & 3.50 & & Often & Good \\
\hline
\end{tabular}

Table 5. Frequency and percentage distribution in solving mathematical word problem using $\mathrm{K}$ to 12 curriculum

\begin{tabular}{|c|c|c|c|}
\hline $\begin{array}{c}\text { Academic } \\
\text { performance }\end{array}$ & Frequency & Percentage & Description \\
\hline $94-100$ & 12 & $13.33 \%$ & $\begin{array}{c}\text { Excellent } \\
\text { performance }\end{array}$ \\
\hline $88-93$ & 28 & $31.11 \%$ & $\begin{array}{c}\text { Superior } \\
\text { performance }\end{array}$ \\
\hline $82-87$ & 36 & $40.00 \%$ & $\begin{array}{c}\text { Average } \\
\text { performance }\end{array}$ \\
\hline $75-81$ & 14 & $15.56 \%$ & $\begin{array}{c}\text { Low } \\
\text { performance }\end{array}$ \\
\hline Below-75 & 0 & $0.00 \%$ & $\begin{array}{c}\text { Very low } \\
\text { performance }\end{array}$ \\
\hline Total & 90 & $100.00 \%$ & \\
\hline
\end{tabular}

Table 6. Correlation Table between the mean status of academic adjustment and performance in solving mathematical word problems using K-12

curriculum

\begin{tabular}{|c|c|c|c|c|}
\hline Variables & $\mathrm{R}$ & $\mathrm{r} 2$ & $\mathrm{p}$-value & Interpretation \\
\hline Attitudes & 0.269283 & 0.07 & 0.010272 & Significant \\
\hline Motivation & 0.222639 & 0.05 & 0.034931 & Significant \\
\hline $\begin{array}{c}\text { Study } \\
\text { Habits }\end{array}$ & 0.371746 & 0.13 & 0.000309 & Significant \\
\hline
\end{tabular}

\section{Discussion}

Table 1 shows academic adjustment of grade VIII students in terms of attitudes, it was found out that item number 1 obtained the highest overall mean rating of 3.73 described as often. It was followed by item number 5 with overall mean of 3.58 described as often. On the other hand, item 4 got 3.49 as its overall mean described as sometimes. Item 3 has an overall mean of 3.48. It shows that item 2 got the lowest overall mean of 3.12. The academic adjustment of grade VIII students in terms of attitudes was perceived as sometimes as indicted by the overall weighted mean score of 3.48 .

Table 2 shows the academic adjustment of grade VIII students in terms of motivation, it was found out that item number 5 obtained the highest overall mean rating of 4.19 described as often. Item 1 , has an overall mean of 3.81 interpreted as often. Item 3 has an overall mean 3.81 described as often. With an overall mean of 3.11 , item 2 shows student as sometimes. Item 4 , obtained an overall mean of 2.99 which has the lowest mean. The academic adjustment of grade VIII students in terms of motivation was perceived as often as indicted by the overall weighted mean score of 3.58.

Table 3 shows academic adjustment of grade VIII students in terms of study habits, it was found out that item number 5 obtained the highest overall mean rating of 3.79 described as often. Item 3 has an overall mean of 3.6 interpreted as often. Item 1 has an overall mean of 3.47 described as sometimes. With an overall mean of 3.28 item 2 shows student as sometimes. Item 4, obtained an overall mean of 2.99 which has the lowest mean interpreted as fair. The academic adjustment of grade VIII students in terms of study habits was perceived as sometimes as indicted by the overall weighted mean score of 3.42 .

Table 4 shows the summary of the mean status of academic adjustment of grade VIII students, it was found out that motivation, obtained the highest overall mean rating of 3.58 described as often and 
interpreted as good. Followed by attitudes has an overall mean of 3.48 described as sometimes and interpreted as fair. Study habits which has the lowest mean with an overall mean of 3.42 described as sometimes and interpreted as fair. The academic adjustment of grade VIII students was perceived as often as indicted by the overall weighted mean score of 3.50 .

Table 5 shows the frequency and percentage distribution in solving mathematical word problem using $\mathrm{K}$ to 12 Curriculum. The data reveal that most of Grade VIII students at Oriental Mindoro National High School have an average performance in solving mathematical word problem having a $40.00 \%$. The excellent and superior performance of the students could be attributed to their positive attitudes towards school or classroom activities.

Table 6 shows the correlation between the mean status of Academic Adjustment and Performance in Solving Mathematical Word Problems using K to 12 Curriculum. The coefficient of determination or r2 for attitudes, motivation, and study habits is 0.07 , 0.05 , and 0.13 respectively. Means that seven percent $(7 \%)$, five percent $(5 \%)$, and thirteen percent $(13 \%)$ of the variation in performance in solving mathematical word problem is due to or can be attributed to the variation in the academic adjustment and the remaining percent's is due to other factors, such as IQ, teacher etc. The computed $\mathrm{p}$-value are $0.010272,0.034931$, and 0.000309 for attitudes, motivation and study habits respectively. In all variables, the computed p-value is less than the alpha $\alpha(0.05)$. It appears that there is a correlation between the said variables to the performance in solving mathematical word problems using $\mathrm{k}$ to 12 Curriculum. Hence, the null hypothesis that there is no significant relationship between mean status of Grade VIII students on academic adjustment and performance in solving mathematical word problems of Grade VIII using K to 12 Curriculum in Oriental Mindoro National High School was rejected.

\section{Conclusion}

Based on the data gathered, the overall mean of attitude was 3.48 and interpreted as "fair."

Motivation had an average weighted mean of 3.58 and interpreted as "good." The interpretation of the study habits had an average weighted mean of 3.42 was "fair." And for the overall mean of the academic adjustment was 3.50 and interpreted as "good."
In terms of the performance in solving mathematical word problems of the grade VIII students results obtained $82 \quad-87$ having forty percent $(40 \%)$ of the learners with verbal interpretation of "average performance."

Through the test of significance, the researcher came up with the following conclusions; the computed p-value are 0.010272, 0.034931, and 0.000309 for attitudes, motivation and study habits respectively. In all variables, the computed $\mathrm{p}$ - value is less than the level of significance at $\alpha(0.05)$. It appears that there is a correlation between the said variables to the academic performance in solving mathematical word problems using $\mathrm{K}$ to 12 curriculum. This means that the performance in solving mathematical word problems using $\mathrm{K}$ to 12 curriculum does affected by the academic adjustment in terms of attitude, motivation and study habits.

\section{Reference}

[1] B. E. Blay, Elementary Statistics (2013)

[2] Mathematics Curriculum - Achieve www.achieve.org/files/g8-m1-teacher-materials.pdf

[3] Preiss and Franova through Abante, E. L. (2011) Cooperative on Mathematics Performance among Fourth Year Students in Puerto Galera National High School Master's Thesis, Divine Word College of Calapan

[4] Navarette et al. through Gardoce, R.M. (2009) Performance of Grade VI pupil in the National Achievement Test in Science and Mathematics in Selected Elementary Schools in Victoria District: An assessment Master's Thesis, Divine Word College of Calapan

[5] Tella (2007) through Singson, N.D. (2015) Predictors in Learning Mathematics and the level of Performance of Grade Six Pupils in Selected Schools in Puerto Galera District: Basis for Intervention Program. Master's Thesis, Divine Word College of Calapan

[6] Ilogu, (2007) through Canuel, C. R. (2011) Problem Solving Approach in Relation to the Mathematics Performance of First Year Students of DVCNHS Matulala Annex Basis for Proposed Program for Innovations in Math Teaching. Master's Thesis, Divine Word College of Calapan

[7] B.F Skinner Operant Conditioning http://www.simplypsychology.org/operant-conditioning. html accessed on November 25, 2015

[8] https://en.wikipedia.org/wiki/Need_theory accessed on December 13, 2015 
International Journal for Cross-Disciplinary Subjects in Education (IJCDSE), Volume 9, Issue 2, June 2018

[9] E. L. Thorndike Theories of Learning http://www.simplypsychology.org/edward-thorndike.html accessed on December 18, 2015

[10] http://www.netmba.com/mgmt/ob/motivation/ mcclelland/ accessed on December 2, 2015

[11] https://en.wikipedia.org/wiki/Operant_conditioning accessed on November 25, 2015 